\title{
IMPROVING LECTURERS' PAEDAGOGIC COMPETENCE THROUGH THE IMPLEMENTATION OF LESSON STUDY IN FACULTY OF TEACHER TRAINING AND EDUCATION OF PAKUAN UNIVERSITY, INDONESIA
}

\author{
Eri Sarimanah ${ }^{1)}$ \\ ${ }^{1)}$ Indonesian Education and Literature Study Program \\ Faculty of Teacher Training and Education of Pakuan University, Indonesia \\ Address: Jln. Pakuan mailbox 452 Bogor West Java Indonesia \\ E-mail: sarimanah.herty@gmail.com
}

\begin{abstract}
This research is aimed at improving the lecturers of Faculty of Teacher Training and Education of Pakuan University paedagogic competence through the implementation of lesson study which covers learning management competence including developing chapter design and lesson design, media making, teaching and learning, evaluation, post evaluation follow-up and learning supervision. This research involves four study program. The method used in this research is qualitative descriptive. The data are collected through documentation, observation, interview and questionnaire. The data are analyzed descriptively to investigate the improvement of the lecturers' paedagogic competence in teaching through the implementation of lesson study. Lesson study has been implemented for two years in Indonesian and Literature Education Study Program, English Education Study Program, Biology Education Study Program, and Primary Education Study Program. The findings show that there is an improvement of the lecturers paedagogic competence in developing chapter design and lesson design, developing material and designing media for learning (plan stage); running the lesson (do stage); and observing the lesson as well as evaluating and reflecting it (see stage). Besides, it is found the lecturers develop learning innovation to create students' active learning. The colleagality among the lecturers is also develop well through the implementation of lesson study. The questionnaire result also shows that the implementation of lesson study can make the student become autonomous learners.
\end{abstract}

Keywors: lecturers' competence. Paedagogic, lesson study

\section{INTRODUCTION}

\section{Background of the Study}

Faculty of Teacher Training and Education of Pakuan University always tries to achieve national education goal and fulfill global demand in order that the graduates able to compete with other graduates nationally and internationally through the improvement of learning quality. By the improvement of learning quality, it is expected that the national education goal can be achieved. One of the efforts to do it is through the improvement of the lecturers' pedagogic competence.

Lecturers' pedagogic competences are among others: 1) understanding learners' characteristics; 2) understanding learners' learning styles and learning difficulties; 30 facilitating the development learners' potency; 4) mastering the theory and the principles of educating learning; 5) developing the curriculum that triggers learners' involvement in learning; 6) designing educated learning; 7) doing educated learning; 8) evaluating the learning process and result.

However, the reality in the field shows first, there are variety of competence and lecturers' difficulty in planning the lesson such as making chapter design and lesson design. Second, in administering the learning process and delivering knowledge, the lecturers have not given optimum effort to give knowledge, skills and attitude to the students by involving them actively. Third, there is no accurate measurement to investigate the students' understanding of the materials and the lecturers' success in teaching and students' succeess in learning and students' learning autonomy. Fourth, the learning process is not relevant the studnts' need.

If those conditions continuously happen, it will result in the low quality of education which cover: 1) the lecturers' uncompetence in planning the lesson; 2) the lowness of learning autonomy and competence of the students in understanding the lecturer's explanation; 3) imperfection in building students' character; 4) students' low thinking capacity.

To anticipate those condition, the lecturers of Faculty of Teacher Training and Education of Pakuan university implement Lesson Study. It is one of the efforts to develop lecturers' quality and professionalism in facilitating the learning process. Lesson study is an activity that encourages a learning community, which consistently and sytematically does self revision individually and managerially. Thus, it is expected that by the implementation of Lesson Study the lecturers' pedadogical competence improved. 


\section{Focus of the Study}

The study focuses on the effort in improving lecturers' pedagogic competence that covers ability to plan a lesson, to administer the students centered-based lesson, and to evaluate the learning process and the learning result through the implementation of Lesson Study. The learning components observed are the lecturers, the students, the materials, the method, the media and the evaluation.

\section{Statement of the Problem}

Based on the background of the study and research focus, the problem can be stated: "Is there an improvement of Faculty of Teacher Training and Education lecturers' pedagogic competence through the implementation of Lesson Study?"

\section{THEORETICAL FOUNDATION}

\section{The Nature of Lecturer's Pedagogic Competence}

The development of science and technology gives impact to the way the lecturers teach. It also encourages them to always improve their competence in order that they are able to use updated material and teaching method that is appropriate with the present situation need and challenge. Thus, the lecturers need to improve their pedagogic competence.

In Indonesian Fundamental Law No. 14 Year 2005 about teacher and lecturer, it is stated that pedagogic competence is "kemampuan mengelola pembelajaran peserta didik" (the ability to manage learners' learning). Department of National Education (2004:9) defines this competence as "kompetensi pengelolaan pembelajaran" (learning management ompetence). This competence can be seen from the ability to plan the learning program, ability to interact with the learners and to manage learning, and aility to evaluate. The competence in planning the lesson according to Joni (1984:12) covers 1) planning the organisation of the learning materials, 2) planning learning management, 3) planning classroom management, 4) planning the use of media and learning resources, and 5) planning learners' learning assessment. Department of National Education (2004:9) sates that the competence of planning a lesson covers 1) ability to describe the goal, 2) ability to select the materials, 3) ability to organize the materials, 4) ability to decide learning strategy/method, 5) ability to decide learning resource and teaching aids, 6) ability to develop evaluation tool, 7) albility to decide evaluation technique, and 8) ability to manage time. Based on the description, designing a lesson is a leacturers' competence towards the activities that the learners should do during the learning process which include stating the goal, describing each lesson, planning the lesson, selecting different media and learning sources, and planning the evaluation based on the goal of learning.

Pedagogic competence is the ability that should be possessed by a lecturer related to the learners characteristics seen from different aspect such as physics, moral, social, culture, emotion, and intellect. Thus, lecturers' pedagogic competence can be described as the whole knowledge, skill and attitude reflected in a set of responsible smart actions possessed by a person whose profession is a teacher.

According to Gagne, there are various indicators showing the competence of a lecturers in teaching if they do the following roles:

1. Teacher as a planner who prepares everything that will be done in the classroom teaching (pre-teaching problems);

2. Teacher as an organizer who creates situation, gives stimulus, moves and leads the learning process based on the plan, in which he plays a role as a resource, and as a wise leadership consultant who is democratic and humanistic during the teaching and learning process.

3. Teacher as an evaluator, who collects, analyzes, interprets, and assesses the success of learning process based on the stated criteria, in terms of the effectiveness of the process and the quality of the product.

Through good understanding about those roles, the lecturers will be able to conduct effective learning that can be seen if the lecturer can achieve the learning target. The learners are able to accept, understand, and apply well the materials delivered by the lecturer. In an effective learning the leacturer's role is very important, because he should know what the learners have already known, what they haven't known, and what they should know. It is expected that a lecturer uses creative and innovative learning method that will make the learners motivated to learn more.

Professional is a quality attitude of a member of a profession towards his profession and degree of their knowledge and expertise they have to do their job. (Surya, 2014:352). Professional teacher is a teacher who is competence and able to use his competence in creating a condition in which the teacher and the students interact to elaborate learning materials. It is also stated that a professional teacher is a teacher who are qualified in planning a lesson and administering the learning process in order to achieve expected specific attitude change.

Besides, teacher professionalism can be seen on teacher's creativity in organizing the learning materials. Teacher's skill in making learning media makes it possible for the students to interact and actively use the learning media. The teachers' competence in conducting the whole evaluation can be seen from both the process and the result by observing students' attitude, students' learning result, and students' skills. In conclusion, teacher professionalism can be reflected through his performance and attitude in doing his job.

\section{The Nature of Lesson Study}

Lesson study is a model of educator profession guidance through analysing learning collaboratively and 
continuously based on the principle of collegiality and mutual learning to develop learning community. (hendayana, 2007:28-38) Lesson study guidance can be used as a teaching guidance model for a teacher or lecturer towards the students, and as an effort to improve teacher's quality and professionalism in facilitating a learning process.

As Lewis stated that if a teacher wants to improve a learning quality, one of the obvious ways is by collaborating with other teachers to design, observe and reflect learning. (Lewis, 2011: 2). Thus, Lesson Study is done in three stages: plan, do, see. The three stages belong to one cycle and is done continuously. In other words Lesson Study is a strategy to improve the quality of education that never ends (continuous improvement).

The improvement of lecturer's pedagogic competence through Lesson Study is done in bottom-up way because the development of learning is done by considering suggestion, criticism, and recommedation from the observers, which is synthesized collaboratively and continuously.

The pattern of Lesson Study is developed as follows:

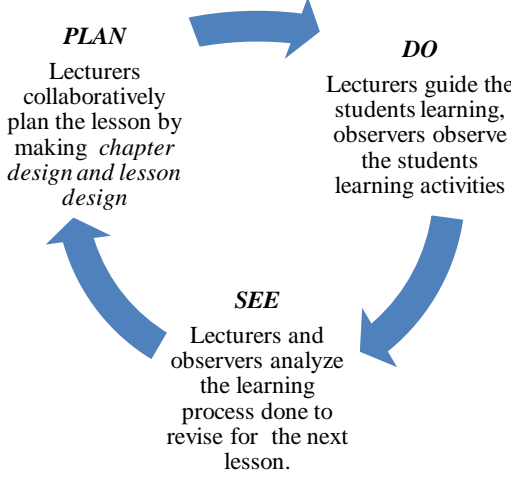

\section{RESEARCH METHOD}

This research applies qualitative descriptive method, and conducted in Indonesian Language and Art Education study program, English Education study program, Biology Education study program, and Primary Education study program.

The result of the research is based on document analysis, observation, and the analysis of the learning process. The research was started by investigating the learning activities done by the lecturers from four different study programs. The instruments used in the research are observational guide and questionnaire. The information is then synthesized to find out the need of lecturer's pedagogic competence in doing learning activity. The target is improving lecturer's pedagogic competence in each study program of Faculty of Teacher Training and Education of Pakuan University which is proven by analysis result.

\section{Research Finding and Discussion}

To find out the effectiveness of Lesson Study program done in Faculty of Teacher Training and
Education of Pakuan University, the researcher compares the condition before and after the implementation of Lesson Study. From the instruments used the researcher got comprehensive information about the situation and condition in the field, because the data are taken from quantitative and qualitative survey. Both are used in the survey before Lesson Study is implemented (baseline survey) and after Lesson Study is implemented (end-line survey) along the learning activities.

Quantitative survey is done through questionnaire distribution and students' academic competence test. The questionnaire is responded by the Head of each study program, the lecturers, and the students. To do the quality assurance of the instrument as the data collection tool in evaluating the effectiveness of the program, those instruments are validated in advance through review, tryout and revision process.

Qualitative survey is done by observing the learning process, interviewing, and analysing video of learning process. The qualitative instruments consist of learning observation guide and interview guide. Those instruments are also developed through review, try-out and revision process.

Monitoring of Lesson Study action is done on every stage of Lesson Study, starting from plan stage, do stage, and see stage. On the plan stage, monitoring is done by directly observing the lecturers' activity of each study program when they plan the lesson. The implementation stage and reflection is done by directly observing the situation and interviewing the model lecturer (the one who carries out the lesson), observers, sample students taken from the open lesson class and the Head of each study program. The monitoring instruments and evaluation used in Lesson Study are as follows:

\section{Data from Interview:}

a. Interview data with lecturers about the condition and situation of the present learning situation

Based on the result of the interview with the lecturers about the present learning situation, the majority of the lecturers said that Lesson Study is a new breakthrough to improve the quality of learning. The lecturer is more skillful in designing the lesson, applying learning model, approach, strategy and the use of learning media. Besides, Lesson Study develops learning community and collaboration among the lecturers so that the success of students' learning can be improved.

b. Interview with students about the condition and situation of the present learning situation

The students conclude that the learning done by the lecturers by implementing Lesson Study can improve their learning motivation, learning strategy, learning autonomy, and learning result.

c. Interview with Head of study program about the condition and situation of the present learning situation 
From the interview with the Head of each study program, it is found that the lecturers' teaching spirit and collegiality among the lecturers improved. The lecturers' pedagogic competence which covers planning, learning action, and reflecting is also improved.

d. Observation and Video analysis of the learning process

Based on the observation of the learning process from the video taken from each lecturer model, it can be seen that in the learning process the students are more active, creative, and joyful. However, the pictural shot is less smooth, neat and appropriate as the result the important moments and expressions are not caught properly by the camera.

e. Academic test in each study program

Academic test of each study program is developed based on the goal of learning of each subject by the team in accordance with the chapter design and lesson design.

\section{Evaluation Data from Lesson Study Activity}

\section{a. Oservation result from Plan stage}

Based on observation result on plan activity, the lecturers agree that before learning is carried out, the lecturers identify the problems to focus on the problems or difficulties that are often faced by the students in particular learning materials. Through Lesson Study the lecturers get used to work collaboratively with other lecturers in deciding learning scenario and learning media that will be used.

This activity is available since Lesson Study is applied. Before Lesson Study was carried out the lecturers worked alone; only a few of them who worked collaboratively with other lecturers who taught the same subject. Through Lesson Study there is an improvement in collaboration among the lecturers.

b. Oservation Result from Learning Activity (Do)

Based on observation result from the learning activity (Do), the lecturers agree with the implementation of Lesson Study because through Lesson Study, all teaching tools are prepared well. The lecturers strongly agree with Lesson Studybased learning. It can be concluded that the implementation of Lesson Study in the learning process shows the improvement of the lecturers' pedagogic competence, as well as the improvement of the students' learning motivation, learning strategy, and learning result.

The improvement of the lecturers' pedagogic competence can be seen by teamwork in plan, do, see stages. Lesson design and chapter design are the products of the lecturers' competence in designing the lesson plan. Before Lesson Study was implemented there were no skills and products as a result of lesson planning design. The benefit of designing the lesson is that the lecturers have a guideline for administering a class which can be measured both its process and its product. In the implementation of Do stage it was found that teaching by being observed triggers the lecturers' creativity in producing learning model and media, Learning innovation can be achieved by many breakthough in learning model and media development as well as the Lesson Study-based research. The model lecturers feel satisfied in conducting Lesson Study. Besides, by conducting a learning reflection, the lecturers are expected to always improve and carry out better lesson.

\section{Data from Questionnaire (Observer)}

Based on the data from questionnaire filled by the oservers, it is found that the observers agree with the implementation of Lesson Study and the stages of plan, do, see. Through Lesson Study they find that the students' learning autonomy improved. Lesson Study can change their perception towards learning process that is open for suggestion and criticism. In conclusion, the observers respond positively to Lesson Study to improve the quality of learning.

\section{Data from Questionnaire (Students)}

The result of questionnaire given to the students show that they are motivated to learn better. The mastery of the lesson with Lesson Study pattern makes the students participate actively in learning the lesson. The lecturing through Lesson Study shows the change of the students' attitude into a more positive one. The students are motivated to learn collaboratively, to be more responsible, and autonomous. Thus, through Lesson Study the students find their own strategy to learn the lesson.

\section{DATA ANALYSIS}

The data taken from questionnaire, observation, and interview are analyzed quantitaively and qualitatively with the following result:

\begin{tabular}{|l|l|l|}
\hline No & The components & Result \\
\hline 1 & Plan & $\begin{array}{l}\text { Almost 100\% lecturers agree } \\
\text { that plan is carried out before } \\
\text { administering the lesson }\end{array}$ \\
\hline 2 & Do & $\begin{array}{l}\text { The lecturers agree that } \\
\text { through Open Lesson all the } \\
\text { learning tools are prepared } \\
\text { well }\end{array}$ \\
\hline 3 & See & $\begin{array}{l}\text { Reflection is effective in } \\
\text { revising the plan before Do } \\
\text { stage }\end{array}$ \\
\hline 5 & Model lecturer & $\begin{array}{l}\text { Lesson Study based learning } \\
\text { reinforces the lecturers to be } \\
\text { professional and competence, } \\
\text { to e able to work }\end{array}$ \\
\hline
\end{tabular}




\begin{tabular}{|l|l|l|}
\hline & & $\begin{array}{l}\text { collaboratively and develop } \\
\text { collegiality }\end{array}$ \\
\hline 6 & Observer & $\begin{array}{l}\text { Almost 100\% lecturers are } \\
\text { motivated to be model } \\
\text { lecturers and believe that } \\
\text { Lesson Study can improve } \\
\text { the quality of learning }\end{array}$ \\
\hline
\end{tabular}

\section{DISCUSSION}

Based on data description and analysis, it can be concluded that Lesson Study is able to:

1. Improve lecturers' skill in designing the lesson, administering the lesson, and evaluating the lesson.

2. Improve collegiality among the lecturers and studentteachers in learning by exchanging experience through Lesson Study.

3. Improve the accountability of lecturers' teaching tasks which are open mind, responsibility, and well planned and evaluated work.

4. Develop learning community among lecturers, among students, and between the lecturers and the students.

5. Improve students' learning autonomy.

6. Improve learning documents and scietific paper writing from learning development result through Lesson Study.

Based on the output, documenting and pulishing Lesson Study activities conducted in four different study programs in Faculty of Teacher Training and Education give positive impact to the lecturers, the students and the study program. They are among others:

1. The availability of innovative and creative learning tools as the result of Lesson Study

2. The documents of Lesson Study results done by Faculty of Teacher Training and Education

3. The improvement of scientific publication as a result of Lesson Study-based research

4. Giving real illustration in improving the leacturers' pedagogic competence.

5. Motivating the lecturers to participate in doing Lesson Study to improve their pedagogic competence and improving the quality of learning.

\section{CONCLUSION}

Learning activity done through the implementation of Lesson Study is proven to improve lecturers' pedagogic competence in designing the lesson by collaborating with other lecturers and giving suggestions to each other in designing the lesson. Before Lesson Study was implemented the lecturers worked alone, but now they work with team so that they have many fruitful suggestions from other lecturers who become the observers. Lesson Study improves the quality of learning, especially through the improvement of lecturers' pedagogic competence in designing, administering, and evaluating the lesson. The implementation of Lesson Study in the class gives positive impact in producing the students who are skillful in learning. The expectation to produce the students who are smart, leading, competitive, and dignitive as expected by the government can be achieved through the implementation of Lesson Study.

\section{REFERENCES}

[1] Creswell, Jhon W. 2008. Educational Research. Planning, Conducting, and Evaluating Quantitative and Qualitative Research. New Jersey:Pearson.

[2] Gagne, Robert M. 2003. Principles of Instructional Design. New York: Holt Rinehart Winston.

[3] Hendayana, Sumar., Sukirman., Karim, MA. 2007. Studi peran IMSTEP dalam penguatan program pendidikan guru MIPA Berbasi Lesson Study di Indonesia. Educationist. Vol 1 (1): 28-38.

[4] Lewis, C. 2002a. Lesson study: A handbook for teacher-led improvement of instruction (Brief guide to lesson study). Philadelphia: Research for better schools online. www.lessonresearch.net/briefguide.pdf.

[5] Lewis, Catherine, \& Jacqueline Hurd. 2011. Lesson Study Step by Step. How TeacherLearning Communitis Improve Instruction. USA Heinemann

[6] Pribadi, Benny A. 2009. Model Desain Sistem Pembelajaran. Jakarta:Dian rakyat.

[7] Trianto. 2007. Model-model Inovatif Berorientasi Konstruktivistik. Surabaya: Prestasi Pustaka Publisher.

[8] Uno, Hamzah. 2006. Perencanaan Pembelajaran. Jakarta: Bumi Aksara.

[9] Twelker, Paul A., Urbach, Floyd D., \& Buck, James E. 1972. The Systematic Development of Instruction. Stanford: ERIC Clearinghouse on Media and Technology. 